\title{
Production and absorption of ammonia in the sheep's stomach
}

\author{
By A. F. PILGRIM, F. V. GRAY AND G. B. BELLING \\ Division of Nutritional Biochemistry, CSIRO, Adelaide, South Australia
}

(Received 23 December 1968-Accepted 6 March 1969)

\begin{abstract}
I. When rumen fluid together with small quantities of $\left({ }^{15} \mathrm{NH}_{4}\right)_{2} \mathrm{SO}_{4},\left[\mathrm{I}^{14} \mathrm{C}\right]$ sodium acetate and polyethylene glycol (PEG) was introduced into the emptied rumen of a sheep, no significan change occurred in the ratio ${ }^{15} \mathrm{~N}:{ }^{14} \mathrm{C}$ during a period of $30-60 \mathrm{~min}$. The ratio ${ }^{15} \mathrm{~N}: \mathrm{PEG}$, however, declined by $22-53 \%$. When $\left({ }^{15} \mathrm{NH}_{4}\right)_{2} \mathrm{SO}_{4},\left[\mathrm{I}^{-14} \mathrm{C}\right]$ sodium acetate and PEG were introduced into the normal rumen of a sheep fed on lucerne hay the ratio ${ }^{15} \mathrm{~N}:{ }^{14} \mathrm{C}$ in the whole rumen contents showed no appreciable change in a period of $\mathrm{I} h$, but the ratio ${ }^{15} \mathrm{~N}: \mathrm{PEG}$ declined by $25-41 \%$. It was therefore concluded that the rate constants for removal of ammonia nitrogen $\left(\mathrm{NH}_{3}-\mathrm{N}\right)$ and volatile fatty acid (VFA) from the rumen were very nearly equal.

2. In sheep fed at $\mathbf{I} \mathrm{h}$ intervals on lucerne hay chaff or lucerne hay pellets VFA production, VFA and $\mathrm{NH}_{3}-\mathrm{N}$ concentration in the rumen fluid and the volume of fluid passed from the rumen to the omasum were determined. From these results and the information previously gained on the relative rates of removal of $\mathrm{NH}_{3}-\mathrm{N}$ and VFA from the rumen, the amounts of $\mathrm{NH}_{3}-\mathrm{N}$ produced in the rumen and absorbed there or at lower levels of the digestive tract were calculated to be equivalent to $23-27 \%$ of the dietary $N$ in lucerne hay chaff and $17 \%$ of that in lucerne hay pellets; $59-66 \%$ of the $\mathrm{NH}_{3}-\mathrm{N}$ was absorbed from the rumen and the remainder passed to the omasum.
\end{abstract}

Since the work of McDonald (1948) on $\mathrm{NH}_{3}$ in the rumen it has been recognized that significant amounts of nitrogen in that form may be absorbed from the forestomachs of ruminants and that the phenomenon may have an important bearing on the value of nitrogenous compounds in the diet.

The work reported here is concerned with measurement of the quantity of ammonia nitrogen $\left(\mathrm{NH}_{3}-\mathrm{N}\right)$ produced in the rumen and absorbed through its wall or passed on to the omasum. An approach to the problem was made through determination of the relative rates of removal of $\mathrm{NH}_{3}-\mathrm{N}$ and VFA from the rumen.

Daily production of $\mathrm{NH}_{3}-\mathrm{N}$ was determined when two forms of lucerne hay were fed to sheep.

\section{EXPERIMENTAL}

\section{Relative rates of absorption of $\mathrm{NH}_{3}$ and $\mathrm{VFA}$ through the rumen wall}

Two series of experiments were carried out, one in sheep from which the bulk of suspended digesta had been removed from the rumen, and the other in sheep in which the rumen contents remained in their normal state. The animals used were Merino ewes aged $3^{-8}$ years and weighing $35-45 \mathrm{~kg}$. The main purpose of the first series was to allow the processes of absorption to be examined at controlled $\mathrm{pH}$ levels. In both series the rates of removal of $\mathrm{NH}_{3}-\mathrm{N}$ and VFA were examined through changes in the concentrations of isotopically labelled $\mathrm{NH}_{3}$ and sodium acetate. The use of a single labelled acid as marker for total VFA has been discussed by Weller, Gray, Pilgrim \& Jones (1967). 
Procedure-series $(a)$. The rumen contents of a fistulated sheep previously fed on finely ground and pelleted lucerne hay were removed through the rumen fistula. The fluid was separated from the bulk of the solids by filtering it through terylene voile and then returning it to the rumen. The rumen was gently massaged, its contents were again removed and the process was repeated until it was judged that only an insignificant amount of solid plant residues remained within the rumen.

Before the test period several litres of rumen fluid were collected from other sheep fed on lucerne hay, centrifuged for $20 \mathrm{~min}$ at $7500 \mathrm{~g}$ and the supernatant fluid was retained. Approximately 31 . of this fluid were taken and to them were added (I) a mixture of acetic, propionic and butyric acids in proportions similar to those in the rumen fluid and in sufficient quantity to bring the $\mathrm{pH}$ to a selected starting value; (2) sufficient $\left(\mathrm{NH}_{4}\right)_{2} \mathrm{SO}_{4}$ to bring the $\mathrm{NH}_{3}-\mathrm{N}$ concentration to a desired level, the range covered in the trials being about 20 to $40 \mathrm{mg} \mathrm{NH}_{3}-\mathrm{N} / 100 \mathrm{ml}$; (3) small quantities of $\left[{ }_{\mathrm{I}}{ }^{14} \mathrm{C}\right]$ sodium acetate (activity about $5 \mu \mathrm{c}$ ) and ${ }^{15} \mathrm{~N}$-labelled $\left(\mathrm{NH}_{4}\right)_{2} \mathrm{SO}_{4}$ (about $0.0 \mathrm{I}-0.02 \mathrm{~g}{ }^{15} \mathrm{~N}$ ); (4) 9-10 $\mathrm{g}$ of PEG. The mixture was brought to a temperature of $40^{\circ}$, a sample removed for analysis and the remainder introduced into the previously emptied rumen. After 5-10 min a sample was withdrawn and incubated at $40^{\circ}$ for the duration of the trial. At intervals during a test period of $30-60 \mathrm{~min}$ samples were taken from the rumen for determination of VFA, $\mathrm{NH}_{3}-\mathrm{N},{ }^{14} \mathrm{C}$ in VFA, ${ }^{15} \mathrm{~N}$ in $\mathrm{NH}_{3}-\mathrm{N}$, and PEG.

The $\mathrm{pH}$ of the fluid during the trials in which it was allowed to change was recorded at each time of sampling. When the $\mathrm{pH}$ was to be maintained constant at a given level, a mixture of unlabelled acetic, propionic and butyric acids was introduced more or less continuously and the $\mathrm{pH}$ monitored, the electrodes of the $\mathrm{pH}$ meter remaining in the rumen throughout the experimental period.

Procedure-series $(b)$. Sheep with rumen fistulas were fed a daily ration of $800 \mathrm{~g}$ lucerne hay pellets in equal lots at intervals of $\mathrm{I} h$ by means of an automatic feeder (Gray, Weller, Pilgrim \& Jones, 1967 ). At the beginning of the test period $100 \mathrm{ml}$ of a solution containing approximately Io $\mu \mathrm{c}$ of $\left[\mathrm{I}^{-14} \mathrm{C}\right]$ sodium acetate, $0.07 \mathrm{~g}{ }^{15} \mathrm{~N}$ in $\left(\mathrm{NH}_{4}\right)_{2} \mathrm{SO}_{4}$, and Io $\mathrm{g} \mathrm{PEG}$, were introduced through the fistula.

Without any further feeding a period of $1-I^{\cdot} 5 \mathrm{~h}$ was allowed to elapse for mixing to be completed and then samples of whole rumen contents ( $15^{\circ}-200 \mathrm{~g}$ ) were removed at I $5 \mathrm{~min}$ intervals over a period of $\mathrm{I}$ h. Each sample of rumen contents was immediately subsampled by a procedure previously described (Gray, Pilgrim \& Weller, I958) to give a $20-25 \mathrm{~g}$ sample for determination of total $\mathrm{N}$ and ${ }^{15} \mathrm{~N}$, and a $40-50 \mathrm{~g}$ sample for determination of moisture. In addition a sample of the rumen fluid was set aside for determination of the concentrations of VFA, ${ }^{14} \mathrm{C}$ and PEG.

\section{Production of $\mathrm{NH}_{3}$ in the rumen in sheep fed on lucerne hay}

A sheep which had been fed for several months on a diet of lucerne hay chaff was given $1000 \mathrm{~g} /$ day in equal lots at intervals of $\mathrm{I} h$. VFA production was measured by the isotope dilution procedure of Weller et al. ( 1967$)$ using a constant infusion of ${ }^{14} \mathrm{C}$-labelled sodium acetate and determining the ${ }^{14} \mathrm{C}$ concentration in the rumen acids in a composite sample of rumen fluid. Each such sample was collected automatically 
over a $24 \mathrm{~h}$ period, and the sampling continued for 4 consecutive days. The complex of radioactive chromium with ethylenediaminetetrachloroacetic acid ( $\left.{ }^{51} \mathrm{CrEDTA}\right)$ was included in the infusion mixture so that it could be introduced into the rumen at a constant rate for the purpose of determining the volume of fluid passed from the rumen to the omasum (Downes \& McDonald, 1964). The concentrations of VFA, $\mathrm{NH}_{3}-\mathrm{N}$ and ${ }^{51} \mathrm{Cr}$ were determined in the composite samples of rumen fluid. Calculations were then made of the amounts of $\mathrm{NH}_{3}-\mathrm{N}$ removed from the rumen, and the amounts passed to the omasum.

The experiment was repeated with a sheep fed on pelleted lucerne hay.

\section{Analytical methods}

VFA and ${ }^{14} \mathrm{C}$ in VFA were determined as previously reported (Weller et al. 1967). PEG was determined by the turbidimetric method of Hydén (1955). Nitrogen in the digesta was determined by the Kjeldahl method and $\mathrm{NH}_{3}-\mathrm{N}$ by the microdiffusion method of Conway (1950) with potassium metaborate as alkaline reagent. To measure ${ }^{15} \mathrm{~N}$ in $\mathrm{NH}_{3}-\mathrm{N}, \mathrm{NH}_{3}$ was distilled from rumen fluid over $\mathrm{MgO}$, neutralized by

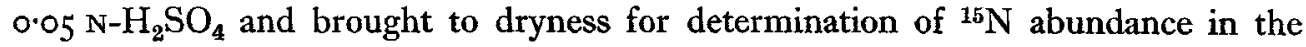
mass spectrometer. ${ }^{15} \mathrm{~N}$ in rumen contents was determined by distilling $\mathrm{NH}_{3}$ from the Kjeldahl digest made alkaline with $\mathrm{NaOH}$, neutralizing as above and determining the ${ }^{15} \mathrm{~N}$ abundance. Radioactivity in the rumen fluid samples was determined by counting in a well-type thallium-activated $\mathrm{NaI}$ crystal.

\section{RESULTS}

\section{Relative rates of absorption of $\mathrm{NH}_{3}$ and $\mathrm{VFA}$ through the rumen wall} Series (a)-washed rumen

Table I shows the concentrations of VFA and $\mathrm{NH}_{3}-\mathrm{N}$ together with the labels ${ }^{15} \mathrm{~N}$ and ${ }^{14} \mathrm{C}$ in the rumen fluid during one of the trials. Table 2 lists the values for the ratio of ${ }^{15} \mathrm{~N}$ to ${ }^{14} \mathrm{C}$ for all of the trials, and also shows the extent of decline in the ratio of ${ }^{15} \mathrm{~N}$ to $\mathrm{PEG}$.

Throughout the series there was little or no change in the concentrations of either $\mathrm{NH}_{3}-\mathrm{N}$ or VFA in the incubated samples, and the concentration of ${ }^{14} \mathrm{C}$ in the VFA in the rumen itself showed practically no change: it was therefore concluded that neither production nor loss of $\mathrm{NH}_{3}$ or VFA occurred in the rumen as a result of any residual fermentation there. The ${ }^{15} \mathrm{~N}$ abundance in the $\mathrm{NH}_{3}-\mathrm{N}$ in the rumen, however, showed some lessening during each of the trials, a change to be expected if urea were entering the rumen in the saliva or through the blood supply to the rumen wall.

Rates of absorption. It is evident from Table 2 that the ${ }^{15} \mathrm{~N}:{ }^{14} \mathrm{C}$ ratio remained substantially constant during each of these trials and therefore the rates of removal of $\mathrm{NH}_{3}-\mathrm{N}$ and VFA (i.e. the proportions of the amounts present that were removed in unit time) were very close to one another. Removal would be partly to the omasum and partly through the rumen wall to the blood stream. Since the rates of removal through the reticulo-omasal orifice to the omasum must have been the same for both substances, it follows that the rates of absorption through the rumen wall must also have 
been very nearly equal. These findings applied to rumen fluid within the $\mathrm{pH}$ range 6-7, whether constant or changing, and to concentrations of $\mathrm{NH}_{3}-\mathrm{N}$ of $20-40 \mathrm{mg}$ / $100 \mathrm{ml}$, and VFA 40-100 m-moles/l.

Table I. Absorption of ammonia nitrogen $\left(\mathrm{NH}_{3}-\mathrm{N}\right)$ and volatile fatty acids (VFA) from rumen fluid introduced into the emptied rumen of the sheep: concentrations of $\mathrm{NH}_{3}-\mathrm{N}$, VFA and markers

\begin{tabular}{|c|c|c|c|c|c|c|c|c|}
\hline \multirow[b]{2}{*}{$\begin{array}{l}\text { Time } \\
\text { (min) }\end{array}$} & \multirow[b]{2}{*}{$\mathrm{pH}$} & \multirow{2}{*}{$\begin{array}{c}\mathrm{NH}_{3}-\mathrm{N} \\
(\mathrm{mg} / \\
100 \mathrm{ml})\end{array}$} & \multirow{2}{*}{$\begin{array}{c}\text { VFA } \\
\text { (m-moles/ } \\
\text { I } 00 \mathrm{ml} \text { ) }\end{array}$} & \multirow[b]{2}{*}{$\begin{array}{c}\text { PEG } \\
(\mathrm{g} / \mathrm{I} 00 \mathrm{ml})\end{array}$} & \multirow[b]{2}{*}{$\begin{array}{c}{ }^{15} \mathrm{~N} \\
(\mathrm{mg} / \mathrm{I} 00 \mathrm{~m}\end{array}$} & \multirow[b]{2}{*}{ 1) $(\mu \mathrm{c} / \mathrm{I}$.0O $\mathrm{ml})$} & \multicolumn{2}{|c|}{ Ratio } \\
\hline & & & & & & & ${ }^{15} \mathrm{~N}:{ }^{14} \mathrm{C}$ & ${ }^{15} \mathrm{~N}: \mathrm{PEG}$ \\
\hline 0 & $6 \cdot 2$ & I $8 \cdot 9$ & $7 \cdot 84$ & 0.283 & 0.375 & 0.132 & $2 \cdot 84$ & I'33 \\
\hline ro & $6 \cdot 5$ & $17 \cdot 6$ & $7 \cdot 18$ & - & 0.345 & 0.120 & 2.88 & - \\
\hline 20 & 6.7 & 16.5 & $6 \cdot 98$ & - & 0.317 & O.II 2 & $2 \cdot 83$ & - \\
\hline 30 & $6 \cdot 9$ & $15 \cdot 9$ & $6 \cdot 38$ & 0.277 & 0.288 & 0.104 & 2.77 & $\mathrm{I} \cdot 04$ \\
\hline \multicolumn{2}{|c|}{$\begin{array}{l}\text { Incubated sample } \\
\text { at } 30 \mathrm{~min}\end{array}$} & 18.9 & $7 \cdot 87$ & - & 一 & 0.132 & - & - \\
\hline
\end{tabular}

Table 2. Ratio of ${ }^{15} \mathrm{~N}$ to ${ }^{14} \mathrm{C}$ and decline in the ratio of ${ }^{15} \mathrm{~N}$ to polyethylene glycol (PEG) during absorption of ammonia nitrogen $\left(\mathrm{NH}_{3}-\mathrm{N}\right)$ and volatile fatty acids $(\mathrm{VFA})$ from rumen fluid introduced into the empty rumen of the sheep

\begin{tabular}{|c|c|c|c|c|c|c|c|c|c|c|c|}
\hline \multirow[b]{2}{*}{ Sheep no. } & \multirow[b]{2}{*}{$\mathrm{pH}$} & \multicolumn{9}{|c|}{ Ratio ${ }^{15} \mathrm{~N}:{ }^{14} \mathrm{C}$ in rumen fluid at times (min): } & \multirow{2}{*}{$\begin{array}{l}\% \text { decline in } \\
\text { ratio }{ }^{15} \mathrm{~N}: \mathrm{PEG}\end{array}$} \\
\hline & & $\circ$ & 10 & 20 & 30 & 40 & 50 & 60 & Mean & SD & \\
\hline I & $6 \cdot 3-6 \cdot 9$ & $4 \cdot 10$ & 3.92 & 3.77 & $3 \cdot 85$ & - & 一 & - & $3 \cdot 91$ & $(0.14 I)$ & 22 \\
\hline 2 & $6 \cdot 4-7 \cdot 0$ & $3 \cdot 88$ & $3 \cdot 81$ & $3 \cdot 69$ & $3 \cdot 45$ & - & - & - & 3.71 & $(0.189)$ & 30 \\
\hline $\mathbf{I}$ & $6 \cdot 2-6 \cdot 9$ & $2 \cdot 84$ & $2 \cdot 88$ & $2 \cdot 83$ & $2 \cdot 77$ & - & - & - & $2 \cdot 83$ & $(0.050)$ & 22 \\
\hline I & $6 \cdot x-6 \cdot 9$ & 4.86 & 4.77 & $5 \cdot 20$ & 5 I0 & $4 \cdot 99$ & - & - & $4 \cdot 98$ & $(0.174)$ & 22 \\
\hline 4 & $6 \cdot 1$ & $4 \cdot 64$ & $4 \cdot 81$ & 5.09 & $5 \cdot 10$ & $5 \cdot 45$ & 5.85 & $5 \cdot 98$ & $5 \cdot 27$ & $(0.507)$ & $2 \mathrm{I}$ \\
\hline 5 & $6 \cdot 2$ & $7 \cdot 63$ & $7 \cdot 34$ & $7 \cdot 54$ & $7 \cdot 63$ & $7 \cdot 53$ & $7 \cdot 98$ & $8 \cdot 16$ & $7 \cdot 69$ & $(0.284)$ & 22 \\
\hline & $6 \cdot 2$ & 4.23 & 4.12 & $4 \cdot 28$ & $4 \cdot 26$ & $4 \cdot 4 I$ & - & - & $4 \cdot 26$ & $(0.104)$ & 20 \\
\hline 3 & $6 \cdot 4$ & $4 \cdot 82$ & 5.03 & 5.71 & $5 \cdot 12$ & $5 \cdot 84$ & $5 \cdot 80$ & $6 \cdot 49$ & $5 \cdot 54$ & $(0.584)$ & 31 \\
\hline 3 & $6 \cdot 4$ & $3 \cdot 92$ & 3.77 & $3 \cdot 84$ & $3 \cdot 89$ & $4 \cdot 27$ & $4 \cdot 10$ & 3.94 & 3.96 & $(0.170)$ & 33 \\
\hline I & $6 \cdot 4$ & 3.68 & 3.56 & 3.66 & $3.9 \mathrm{I}$ & 3.94 & $3 \cdot 56$ & 3.82 & $3 \cdot 75$ & $(0.144)$ & 27 \\
\hline 4 & $6 \cdot 6$ & 4.04 & 3.84 & 3.79 & $3 \cdot 84$ & $3.9 \mathrm{I}$ & 3.63 & 4.00 & 3.86 & $(0.137)$ & 33 \\
\hline 3 & $6 \cdot 8$ & 3.91 & 4.05 & 3.93 & $4 \cdot 18$ & 4.00 & $3 \cdot 82$ & 3.44 & 3.90 & $(0.234)$ & 53 \\
\hline I & $6 \cdot 8$ & $4 \cdot 19$ & $4 \cdot 33$ & $4 \cdot 40$ & 3.86 & $3 \cdot 64$ & $3 \cdot 74$ & 3.79 & $3 \cdot 99$ & $(0.307)$ & 39 \\
\hline
\end{tabular}

Extent of absorption through rumen wall. The ratios of ${ }^{15} \mathrm{~N}$ and ${ }^{14} \mathrm{C}$ to the unabsorbed marker PEG showed a decline with time due to absorption of $\mathrm{NH}_{3}-\mathrm{N}$ and VFA ('Table 2). The extent of this decline varied from 20 to $53 \%$ of the initial values during the series.

\section{Series $(b)$-normal rumen}

The ${ }^{15} \mathrm{~N}:{ }^{14} \mathrm{C}$ ratios for all the trials in this series are given in Table 3 . It is again evident from the constancy of the ratios that the rates of removal of $\mathrm{NH}_{3}-\mathrm{N}$ and VFA from the rumen were very nearly equal. There was substantial absorption during the experimental period as indicated by the decline that occurred in the ${ }^{15} \mathrm{~N}$ : $\mathrm{PEG}$ ratio in $\mathrm{I} h$. The sheep in this series were fed throughout the day and the $\mathrm{pH}$ of the rumen fluid remained fairly steady between $6 \cdot 1$ and $6 \cdot 3$. 


\section{Production of $\mathrm{NH}_{3}$ in the rumen of sheep fed on lucerne hay}

Results for the 4 consecutive days of each trial are given in Table 4 , and the following example illustrates the calculations made in arriving at the findings given in Table 5, which summarizes the results of the two trials.

Sheep given $1000 \mathrm{~g}$ lucerne hay chaff: $\mathrm{N}=27 \cdot 2 \mathrm{~g} /$ day.

Production of VFA in rumen $=3.98$ moles/day.

Mean concentration $\mathrm{NH}_{3}-\mathrm{N}$ in rumen fluid $=0.173 \mathrm{~g} / \mathrm{l}$.

Mean concentration VFA in rumen fluid $=0.102$ moles $/ 1$.

Table 3. Ratio of ${ }^{15} \mathrm{~N}$ to ${ }^{14} \mathrm{C}$ and decline in the ratio of ${ }^{15} \mathrm{~N}$ to polyethylene glycol (PEG) during absorption of ammonia nitrogen $\left(\mathrm{NH}_{3}-\mathrm{N}\right)$ and volatile fatty acids (VFA) from normal rumen contents of the sheep

\begin{tabular}{|c|c|c|c|c|c|c|c|c|}
\hline \multirow{2}{*}{$\begin{array}{c}\text { Sheep } \\
\text { no. }\end{array}$} & \multicolumn{5}{|c|}{ Time (min) } & \multirow[b]{2}{*}{ Mean } & \multirow[b]{2}{*}{ SD } & \multirow{2}{*}{$\begin{array}{c}\% \text { decline } \\
\text { in ratio } \\
{ }^{5} \mathbf{N}: \text { PEG }\end{array}$} \\
\hline & 0 & 15 & 30 & 45 & 60 & & & \\
\hline I & I I 4 & I I 3 & $12 \cdot 5$ & $12 \cdot 2$ & 10.2 & II. 5 & $(0.899)$ & 4I \\
\hline 2 & 10.3 & 10.7 & $10 \cdot 0$ & $9 \cdot 7$ & 9.4 & 10.0 & $(0.507)$ & 28 \\
\hline I & 10.4 & I I'2 & I I'O & $12 \cdot 0$ & I2.7 & II 5 & $(0.899)$ & 39 \\
\hline 2 & $12 \cdot 4$ & II.O & $9 \cdot 4$ & 10.3 & 10.3 & 10.7 & $(I \cdot I 2)$ & 29 \\
\hline 3 & $I I \cdot 0$ & I I $\cdot 2$ & $11 \cdot 4$ & $12 \cdot 4$ & $12 \cdot 6$ & II 7 & $(0.729)$ & 25 \\
\hline
\end{tabular}

Table 4. Production of volatile fatty acids (VFA) and concentrations of VFA and ammonia nitrogen $\left(\mathrm{NH}_{3}-\mathrm{N}\right)$ in the rumen of sheep fed lucerne hay

VFA conc. in

VFA produced rumen fluid

Day no. (moles/day) (m-moles/l.)
CrEDTA

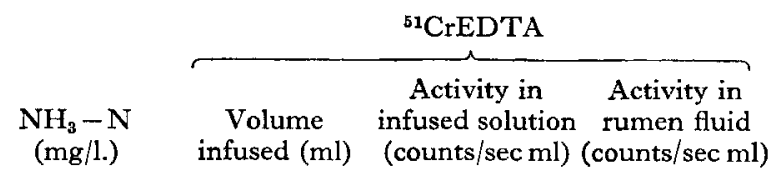

Sheep fed lucerne hay chaff- $27.2 \mathrm{~g} \mathrm{~N} /$ day

$\begin{array}{crrrr}102 & 173 & 1030 & 26 \cdot 6 & 1 \cdot 95 \\ 124 & 250 & 1000 & 26 \cdot 6 & 2 \cdot 80 \\ 108 & 192 & 995 & 26.6 & 1 \cdot 94 \\ 96.6 & 190 & 980 & 26.6 & 1 \cdot 83\end{array}$

$108 \quad 201$

Sheep fed lucerne hay pellets-28.4 g N/day

$\begin{array}{ccccc}106 & 154 & 1050 & 26 \cdot 6 & 2 \cdot 27 \\ 82 \cdot 2 & 124 & 1060 & 26 \cdot 6 & 1 \cdot 79 \\ 105 & 170 & 1039 & 26 \cdot 6 & 2 \cdot 53 \\ 103 & 170 & 980 & 26 \cdot 6 & 2 \cdot 62\end{array}$

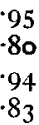

27

79

$2 \cdot 62$

$99 \cdot 0$

155

EDTA, ethylenediaminetetrachloroacetic acid

Since the rate constants of removal of $\mathrm{NH}_{3}-\mathrm{N}$ and VFA from the rumen were found to be equal

$$
\frac{\mathrm{NH}_{3}-\mathrm{N} \text { removed }(\mathrm{g})}{\mathrm{NH}_{3}-\mathrm{N}(\mathrm{g} / \mathrm{l} .) \times V(\mathrm{l} .)}=\frac{\text { VFA removed (moles) }}{\text { VFA }(\text { moles } / \mathrm{l}) \times V(1 .)},
$$


where $V=$ volume of rumen fluid. And since the amounts produced in the day can be considered equal to the amounts removed,

$$
\mathrm{NH}_{3}-\mathrm{N} \text { produced }=\mathrm{NH}_{3}-\mathrm{N} \text { removed }=\frac{3 \cdot 98 \times 0 \cdot 173}{0.102}=6.75 \mathrm{~g} \mathrm{~N} / \text { day, }
$$

${ }^{51}$ CrEDTA:infusion $103^{\circ} \mathrm{ml} /$ day: radioactivity $26 \cdot 6 \equiv$ counts/sec per $\mathrm{ml}$, rumen fluid radioactivity $\equiv \mathrm{I} \cdot 95$ counts/sec per $\mathrm{ml}$.

Therefore volume of fluid passed from rumen to omasum $=14 \cdot \mathrm{I} 1 . /$ day.

Therefore $\mathrm{NH}_{3}-\mathrm{N}$ passed to omasum $=14 \cdot 1 \times 0.173=2 \cdot 43 \mathrm{~g} \mathrm{~N} /$ day.

Thus of the $6 \cdot 75 \mathrm{~g} \mathrm{NH}_{3}-\mathrm{N}$ produced in and removed from the rumen, $4 \cdot 32 \mathrm{~g}$ were absorbed through the rumen wall and $2.43 \mathrm{~g}$ were passed to the omasum. It can be seen from Table 5 that production of $\mathrm{NH}_{3}-\mathrm{N}$ varied very little between the 4 days; it was equivalent to $23-27 \%$ of the dietary $\mathrm{N}$ when lucerne hay chaff was fed, and to $17 \%$ when the same hay was given in pellet form; $59-66 \%$ of this $\mathrm{NH}_{3}-\mathrm{N}$ was absorbed from the rumen itself.

Table 5. Production of ammonia nitrogen $\left(\mathrm{NH}_{3}-\mathrm{N}\right)$ in the sheep fed lucerne hay

\begin{tabular}{|c|c|c|c|c|c|}
\hline & & & Production & $\mathrm{NH}_{3}-\mathrm{N}$ & \\
\hline Day no. & $\begin{array}{l}\text { Fluid passed to } \\
\text { omasum (1./day) }\end{array}$ & $\begin{array}{l}\mathrm{NH}_{3}-\mathrm{N} \\
\text { absorbed from } \\
\text { rumen }(\mathrm{g} / \text { day) }\end{array}$ & $\begin{array}{l}\mathrm{NH}_{3}-\mathrm{N} \text { passed } \\
\text { to omasum } \\
\text { (g/day) }\end{array}$ & $\begin{array}{l}\text { Total } \\
\text { production } \\
\text { (g/day) }\end{array}$ & $\begin{array}{l}\text { Production as } \\
\% \text { of dietary } \mathrm{N}\end{array}$ \\
\hline
\end{tabular}

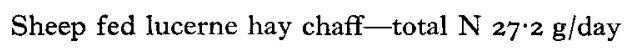

$\begin{array}{rllll}14.1 & 4.32 & 2.43 & 6.75 & 25 \\ 9.5 & 4.60 & 2.38 & 6.98 & 26 \\ 13.7 & 3.76 & 2.62 & 6.38 & 23 \\ 14.2 & 4.57 & 2.71 & 7.28 & 27 \\ 12.9 & 4.31 & 2.53 & 6.84 & 25\end{array}$

Sheep fed lucerne hay pellets--total N $28.4 \mathrm{~g} /$ day

$\begin{array}{crrrrr}1 & 12.3 & 2.84 & 1.89 & 4.73 & 17 \\ 2 & 15.7 & 3.01 & 1.95 & 4.96 & 17 \\ 3 & 10.9 & 3.08 & 1.86 & 4.94 & \text { I7 } \\ 4 & 9.9 & 3.23 & 1.69 & 4.92 & 17 \\ \text { Mean } & 12.2 & 3.04 & 1.85 & 4.89 & 17\end{array}$

\section{DISCUSSION}

The $\mathrm{pH}$ of the rumen contents of sheep can be said commonly to lie between 6 and 7 although on some diets lower values are found, and during starvation or when large amounts of urea are given it often rises above 7 .

It is known that VFA are absorbed faster at low than at high $\mathrm{pH}$ values in the rumen fluid and it has been suggested that this is due to the fact that un-ionized molecules of the acids may penetrate the lipoid layers of cell membranes whereas VFA ions may be limited to diffusion through water-filled pores (Danielli, Hitchcock, Marshall \& Phillipson, 1945). Examination of the dissociation curves of the acids 
Vol. 23

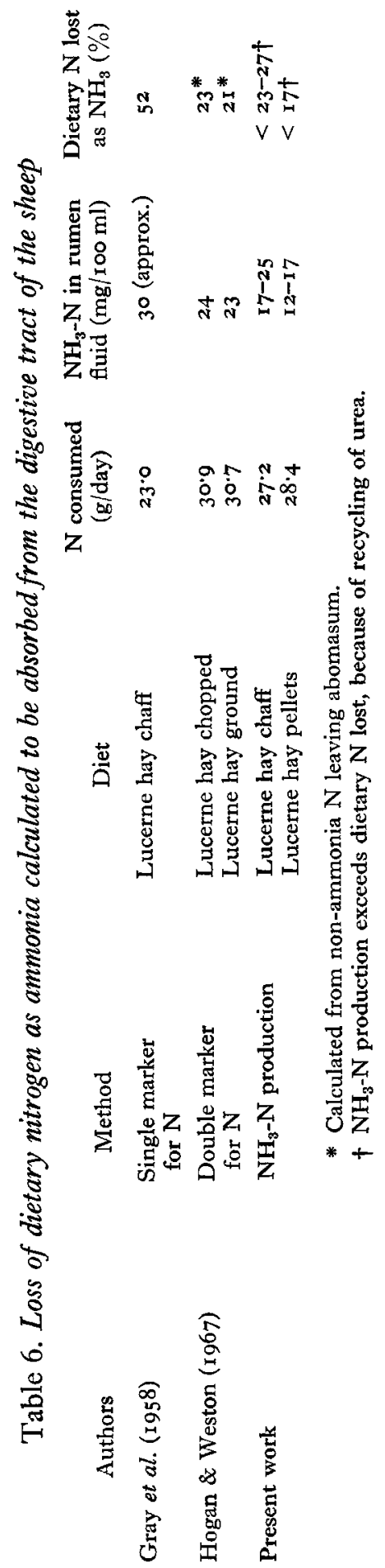


indicates that on this basis there could be marked changes in the rate of absorption between $\mathrm{pH} 6$ and $\mathrm{pH}_{4}$, but relatively little within the range $\mathrm{pH} 6-7$ (Aafjes, 1967 ). While it is unlikely that the absorption can be explained fully in this way it appears that $\mathrm{pH}$ does affect the rates of absorption; but there is no evidence that the effect would be at all marked in the $\mathrm{pH}$ range used in the work reported here.

There is also little doubt that one of the main factors that could influence the rate of absorption of $\mathrm{NH}_{3}$, apart from its concentration, is the $\mathrm{pH}$ of the rumen fluid and this has been attributed to the fact that the ammonium ion does not penetrate cell membranes rapidly in comparison with the undissociated molecule (Hogan, r96r ; Coombe, Tribe \& Morrison, 1960). The effect of $\mathrm{pH}$ on $\mathrm{NH}_{3}$ absorption would therefore be expected to be opposite to that on VFA absorption. But again it cannot be concluded that absorption would be much affected in the $\mathrm{pH}$ range $6-7$. It has been pointed out that other factors may play a part in absorption and that the effective $\mathrm{pH}$, i.e. the $\mathrm{pH}$ at the site of absorption, may be different from that of the rumen fluid in general (Sperber, 1968).

All of the trials reported here were carried out within the $\mathrm{pH}$ range $6-7$ and the results indicate that any effects that $\mathrm{pH}$ may have had on the rates of absorption of ${ }^{15} \mathrm{~N}$ or ${ }^{14} \mathrm{C}$ were insufficient to change the ratio of the one to the other in the rumen.

The experiments have provided information on the amounts of $\mathrm{NH}_{3}-\mathrm{N}$ produced in the rumen and absorbed there or at lower levels of the digestive tract. There is, however, always some recycling of urea to the rumen and consequently the quantities of $\mathrm{NH}_{3}-\mathrm{N}$ reported in Table 5 represent only the upper limits to the loss of useful $\mathrm{N}$ to the animal through $\mathrm{NH}_{3}$ formation.

A number of attempts have been made to approach the problem of such losses by measuring the amounts of $\mathrm{N}$ passing through the abomasum or small intestine. Recent reports (Balch, 1957; Harris \& Phillipson, 1962; Clarke, Ellinger \& Phillipson, r966; Hogan \& Weston, 1967) are in agreement with the earlier finding of Gray \& Pijgrim (1956) that when the $\mathrm{N}$ content of the diet is low there can be a net gain of $\mathrm{N}$ in the rumen, presumably through microbial use of recycled urea, while at higher levels of $\mathrm{N}$ in the diet there can be a net loss due to absorption of $\mathrm{NH}_{3}$. It has been shown, however, that the use of $\mathrm{N}$ :lignin ratios on which the original finding was based must lead to overestimation of the loss of $\mathrm{N}_{\text {by }} \mathrm{NH}_{3}$ formation (Bruce, Goodall, Kay, Phillipson \& Vowles, I966; Hogan \& Weston, I967). Although the results reported here are not intended to indicate net losses of useful $\mathrm{N}$ they may be compared with the findings of Hogan \& Weston ( 1967 ) on the passage of $\mathrm{N}$ from the abomasum to the small intestine during the feeding of a similar diet. It can be seen from Table 6 that the values for $\mathrm{NH}_{3}-\mathrm{N}$ production and absorption are consistent with the later report rather than with the original work based on $\mathrm{N}$ : lignin ratios (single marker method). But it should be noted that the amount of $\mathrm{N}$ given was smaller and the concentration of $\mathrm{NH}_{3}-\mathrm{N}$ greater in the early experiment and this would be expected to lead to a greater proportion of dietary $\mathrm{N}$ being lost through $\mathrm{NH}_{3}$ absorption.

We thank Miss M. A. Horn and Mr P. R. Clements for their assistance with the experimental procedures. 


\section{REFERENCES}

Aafjes, J. H. (1967). Z. Tierphysiol. Tierrenähr. Futtermittelk. 22, 69.

Balch, C. C. (1957). Br. F. Nutr. Ir, 2 I3.

Bruce, J., Goodall, E. D., Kay, R. N. B., Phillipson, A. T. \& Vowles, L. E. (1966). Proc. R. Soc. B I66, 46.

Clarke, E. M. W., Ellinger, G. M. \& Phillipson, A. T. (1966). Proc. R. Soc. B r66, 63.

Conway, E. J. (1 950). Microdiffusion Analysis and Volumetric Error, 3 rd ed. London: Crosby, Lockwood $\&$ Son Ltd.

Coombe, J. B., Tribe D. E. \& Morrison, J. W. C. (1960). Aust. F. agric. Res. Ir, 247.

Danielli, J. F., Hitchcock, M. W. S., Marshall, R. A. \& Phillipson, A. T. (1945). F. exp. Biol. 22, 75.

Downes, A. M. \& McDonald, I. W. (1964). Br. F. Nutr. 18, I 53.

Gray, F. V. \& Pilgrim, A. F. (1956). Nature, Lond. 178, 94.

Gray, F. V., Pilgrim, A. F. \& Weller, R. A. (1958). Br. F. Nutr. 12, 4I3.

Gray, F. V., Weller, R. A., Pilgrim, A. F. \& Jones, G. B. (1967). Aust. Y. agric. Res. r8, 625.

Harris, L. E. \& Phillipson, A. T. (1962). Anim. Prod. 4, 97.

Hogan, J. P. (196r). Aust. F. biol. Sci. r4, 448.

Hogan, J. P. \& Weston, R. H. (1967). Aust. F. agric. Res. 18, 803.

Hydén, S. (1955). LantbrHögsk. Annlr 22, 139.

McDonald, I. W. (1948). Biochem. Y. 42, 384 .

Sperber, I, (1968). In Isotope Studies on the Nitrogen Chain. Vienna: International Atomic Energy Agency.

Weller, R. A., Gray, F. V., Pilgrim, A. F. \& Jones, G. B. (I967). Aust. F. agric. Res. r8, 107. 